\title{
Pelatihan Tanda Tangan Digital dalam Perkuliahan Online untuk Mengurangi Manipulasi Presensi
}

\author{
Baiq Rina Amalia Safitri, Baiq Azmi Sukroyanti, Lovy Herayanti, Pahriah, Dewi \\ Nadiani
}

Fakultas Sains, Teknik dan Terapan, Universitas Pendidikan Mandalika, Jl. Pemuda No. 59

A, Mataram, Indonesia 83125

*Email Korespondensi: bqrinaamaliasafitri@ikipmataram.ac.id dan 081917085141

\section{Diterima: Februari 2021; Revisi: April 2021; Diterbitkan: Mei 2021}

\begin{abstract}
Abstrak
Perguruan tinggi di Indonesia, telah meliburkan kegiatan pembelajaran tatap muka dan meminta dosen untuk melakukan aktivitas belajar dari rumah secara daring. Aturan tentang kewajiban hadir dalam perkuliahan minimal $75 \%$ dan kehadiran memiliki bobot nilai $20 \%$. Salah satu cara yang dapat dilakukan dalam mengatasi hal tersebut adalah dengan menggunakan aplikasi tanda tangan digital dan memanfaatkan aplikasi yang dimiliki google yaitu google drive yang dapat difungsikan untuk mengisi kehadiran online. Tujuan dari pelatihan ini adalah ingin membuat presensi yang mudah dan transparan bagi mahasiswa. Jumlah peserta dalam pelatihan adalah 20 mahasiswa pendidikan teknologi informasi. Metode yang digunakan dalam pelatihan yakni metode diskusi dan metode latihan. Materi yang akan disampaikan, antara lain: a) cara menginstal TTDigital; b) cara mengoprasian TTDigital; c) cara mengisi absen online. Hasil dari pelatihan ini yakni memperlihatkan bahwa mahasiswa mampu membuat TTDigital untuk mengisi presensi online yakni terbukti dengan hasil tanda tangan mahasiswa pada link drive yang saya kirim, apabila terdapat mahasiswa dengan kosong TTDigital berarti mahasiswa tersebut tidak mengikuti perkuliahan. Sehingga, pelatihan ini membantu mahasiswa dalam pengisian kehadiran dan membantu dosen dalam melihat dan merekapitulasi kehadiran mahasiswa.
\end{abstract}

Kata Kunci: kehadiran; TTDigital; perkuliahan

\section{Digital Signature Training in Online Lectures to Reduce Attendance Manipulation}

\begin{abstract}
Most universities in Indonesia have closed face-to-face learning activities and asked lecturers to carry out learning activities from home online. The rules regarding the obligation to attend lectures are at least $75 \%$ and attendance has a score of $20 \%$. One way that can be done to overcome this is by using a digital signature application and utilizing an application owned by Google, namely Google Drive, which can be used to fill online presence. The purpose of this training is to create an easy and transparent presence for students. The number of participants in the training was 20 students of information technology education. The methods used in the training are the discussion method and the training method. The materials to be delivered include: a) how to install TTDigital; b) how to operate TTDigital; c) how to fill in online timesheet. The results of this training showed that $100 \%$ of the students attended the lecture, which was proven by having 16 TTDigital which were filled online and if there were students with blank TTDigital, it meant that the student was not taking the lecture. So, this training helps students in filling in attendance and helps lecturers to see and recapitulate student attendance.
\end{abstract}

Keywords: presence; TTDigital; lectures

How to Cite: Safitri, B. R. A., Sukroyanti, B. A., Herayanti, L., Pahriah, P., \& Nadiani, D. (2021). Pelatihan Tanda Tangan Digital dalam Perkuliahan Online untuk Mengurangi Manipulasi Presensi. Lumbung Inovasi: Jurnal Pengabdian Kepada Masyarakat, 6(1), 16-21. https://doi.org/10.36312/linov.v6i1.420 


\section{PENDAHULUAN}

Perguruan tinggi di Indonesia, telah meliburkan kegiatan pembelajaran tatap muka dan meminta dosen untuk melakukan aktivitas belajar dari rumah secara daring. Perkuliahan yang dilakukan secara online, menyebabkan bukti kehadiran perkuliahan tidak dapat dilakukan secara manual dan hanya dapat dilakukan secara online. Menurut Indah (2019), salah satu teknologi yang berkembang dengan cepat adalah absensi online.

Kita memaknai absensi dengan kehadiran, namun hal ini keliru. Kata ini kita serap dari bahasa Belanda 'absentie' yang maknanya 'ketidakhadiran'. Lawan katanya adalah 'presentie' yang bermakna 'kehadiran'. Dalam bahasa Inggris dia disebut dengan 'absence' dan lawan katanya adalah 'attendance' (Kompas, 2013).

Aturan tentang kewajiban hadir minimal $75 \%$ dalam suatu mata kuliah merupakan aturan umum yang sudah diketahui bersama (Kompas, 2014). Hal ini sejalan dengan Buku pedoman akademik FPMIPA IKIP Mataram (2015). Peraturan kewajiban presensi $75 \%$ dalam praktiknya, dapat diartikan bahwa bila dalam 1 periode mata kuliah ada 16 kali pertemuan, maka mahasiswa wajib hadir minimal pada 12 kali pertemuan (75\% dari 16). Selain itu juga dalam peraturan pemberian nilai akhir mahasiswa, kehadiran memiliki bobot nilai $20 \%$.

Banyak dosen melakukan perkuliahan dengan whatsaap sehingga kehadiran mahasiswa pun dilakukan dengan mengetik nama langsung di whatsaap tersebut, dan peluang manipulasi kehadiran mahasiswa yang sebenarnya tidak mengikuti perkuliahan menjadi lebih besar, seperti disajikan pada Gambar 1.

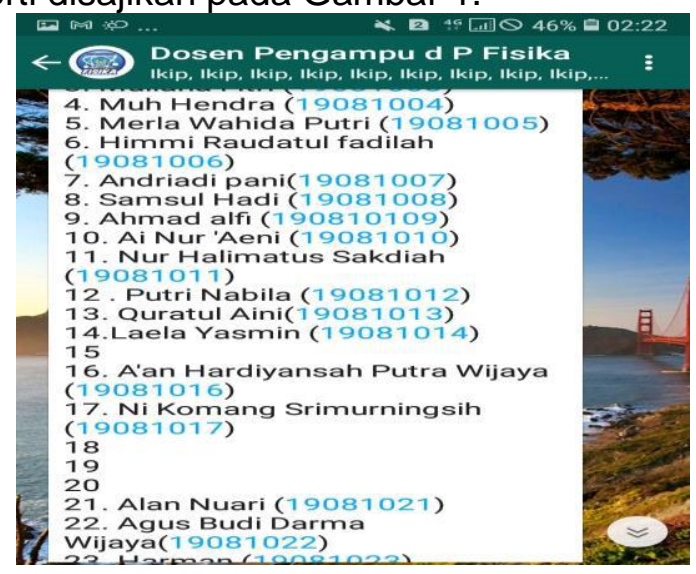

Gambar 1. Pengisian presensi perkuliahan

Salah satu cara yang dapat dilakukan dalam mengatasi hal tersebut adalah dengan menggunakan aplikasi tanda tangan digital dan memanfaatkan aplikasi yang dimiliki google yaitu google drive yang dapat difungsikan untuk mengisi kehadiran online. Dimana, tanda tangan digital (TTDigital) adalah suatu tanda tangan biasa yang dibuat secara elektronik yang berfungsi sama dengan tanda tangan biasa pada dokumen kertas biasa (Hestanto, 2020). Sedangkan, google drive menurut Ainun (2019) adalah media penyimpanan data online (daring) berbasis cloud atau internet yang dikembangkan dan diperkenalkan oleh google.

\section{METODE PELAKSANAAN Persiapan Pelatihan}

Sebelum melakanakan kegiatan, maka perlu dilakukan beberapa hal sebagai bentuk persiapan, yakni: membuat tutorial materi pengabdian. Materi yang akan disampaikan kepada mahasiswa dalam pelatihan membuat tanda tangan digital dan mengisi kehadiran secara online, antara lain: a) cara menginstal TTDigital; b) cara mengoprasian TTDigital; c) cara mengisi absen online.

\section{Pelaksanaan Pelatihan}

Tujuan dari pelatihan ini adalah ingin membuat presensi yang mudah dan transparan bagi mahasiswa. Peserta dalam kegiatan ini adalah mahasiswa program studi pendidikan teknologi informasi UNDIKMA adalah 20 mahasiswa. Metode yang digunakan dalam pelatihan yakni metode diskusi dan metode latihan. Dimana, Diskusi adalah pertukaran pikiran (sharing 
of opinion) antara dua orang atau lebih yang bertujuan memperoleh kesamaan pandang tentang sesuatu masalah yang dirasakan bersama (Samani, 2012). Menurut Ermi (2015), diskusi merupakan suatu metode pembelajaran yang di dalamnya terdapat percakapan antara individu dengan indvidu lainnya yang terbentuk ke dalam wadah atau kelompok yang dihadapkan oleh suatu permasalahan sehingga mereka dapat bertukar pikiran untuk mendapatkan pemecahan masalah yang benar melalui kesepakatan bersama.

Rusman (2011) menyatakan bahwa metode latihan menurut beberapa pendapat memiliki pengertian sebagai berikut: suatu teknik yang dapat diartikan sebagai suatu cara mengajar di mana peserta didik melaksanakan kegiatan latihan, peserta didik memiliki ketangkasan atau keterampilan yang lebih tinggi dari apa yang telah dipelajari. Suatu kegiatan dalam rnelakukan hal yang sama secara berulang-ulang dan sungguh-sungguh dengan tujuan untuk memperkuat asosiasi atau menyempurnakan suatu keterampilan supaya menjadi permanen (Ferry, dkk., 2014).

Pelaksanaan pelatihan melalui group whatsApp, materi diberikan dalam bentuk tutorial yang dikirim melalui whatsApp. Pertama yang dilakukan adalah mengirimkan materi, antara lain: a) cara menginstal TTDigital. b) cara mengoprasian TTDigital. c) cara mengisi absen online melalui google drive. Kedua mengirimkan link goole drive untuk pengisian kehadiran, link google drive yaitu https://docs.google.com/spreadsheets/d/1x5ViYqOh2DGPPyjfvMR0oRtQCLWxfx_MzaHZV34/edit?usp=drivedk. Ketiga memberikan kesempatan kepada para peserta pelatihan untuk memperaktekkannya dan diskusi.

Pemantauan pelaksanaan pelatihan dapat dilakukan melalui group whatsApp dan link google drive. Munculnya pertanyaan-pertanyaan dari para peserta dan diskusi pun berlangsung saat pelatihan yang dilakukan melaui group whatsApp. Keberhasilan para peserta dapat dilihat dari tanda tangan digital yang sudah dibuat pada link google drive yang dikirmkan.

\section{HASIL DAN PEMBAHASAN}

Pelatihan ini dilaksanakan pada tanggal 21 September 2020 sampai 27 September 2020 pada mahasiswa program studi pendidikan teknologi informasi UNDIKMA. Bentuk kegiatan dalam pelatihan ini adalah pelatihan membuat tanda tangan digital dan mengisi kehadiran secara online. Manfaat dari pelatihan ini adalah sebagai berikut: mahasiswa dapat membuat tanda tangan digital sendiri dan mampu mengisi kehadiran kuliah secara online. Peserta dalam kegiatan ini adalah mahasiswa program studi pendidikan teknologi informasi UNDIKMA. Fasilitator dalam kegiatan ini adalah dosen UNDIKMA yang mengajar di Fakultas Sains, Teknik dan Terapan.

Pertama-tama membagikan materi berupa tutorial tentang membuat tanda tangan digital dan mengisi kehadiran online kepada para peserta pelatihan. Penyampaian materi pelatihan melalui aplikasi whatsaap, supaya para peserta dapat melihat langsung sehingga para peserta dapat memperaktikkan langsung serta dapat menanyakan secara langsung apabila ada kesulitan. Materi yang disampaikan kepada para peserta pelatihan, antara lain.

\section{Instalasi TTDigital}

Membuka Aplikasi Play Store, kemudian ketik ditelusur aplikasi TTDigital dan tekan Instal, seperti terlihat pada Gambar 2 dan Gambar 3.

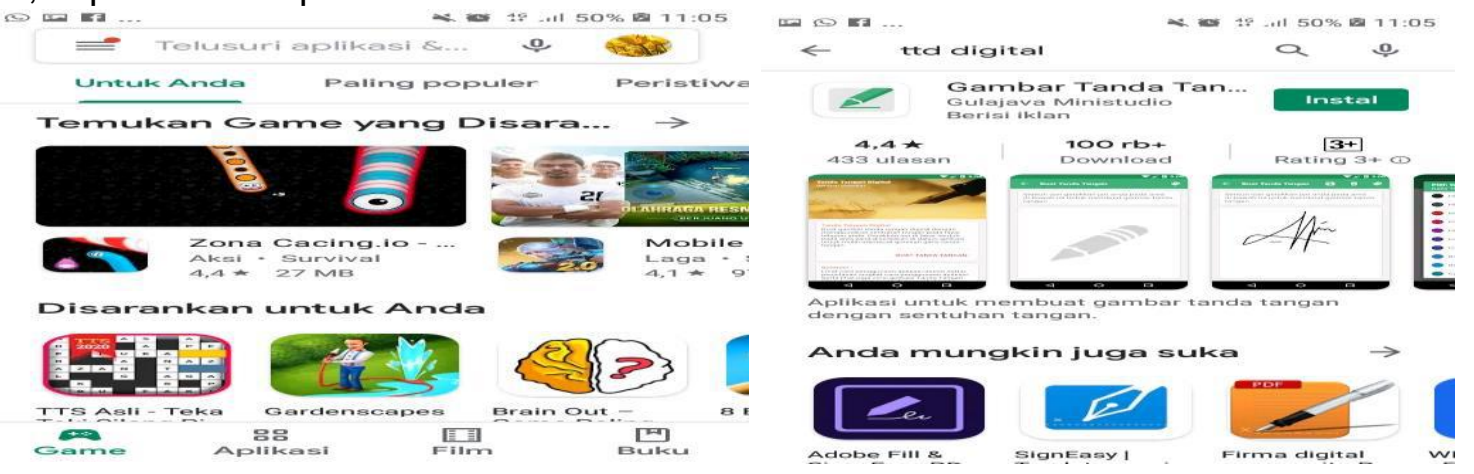

Gambar 2. Aplikasi TTDigital pada Playstore 


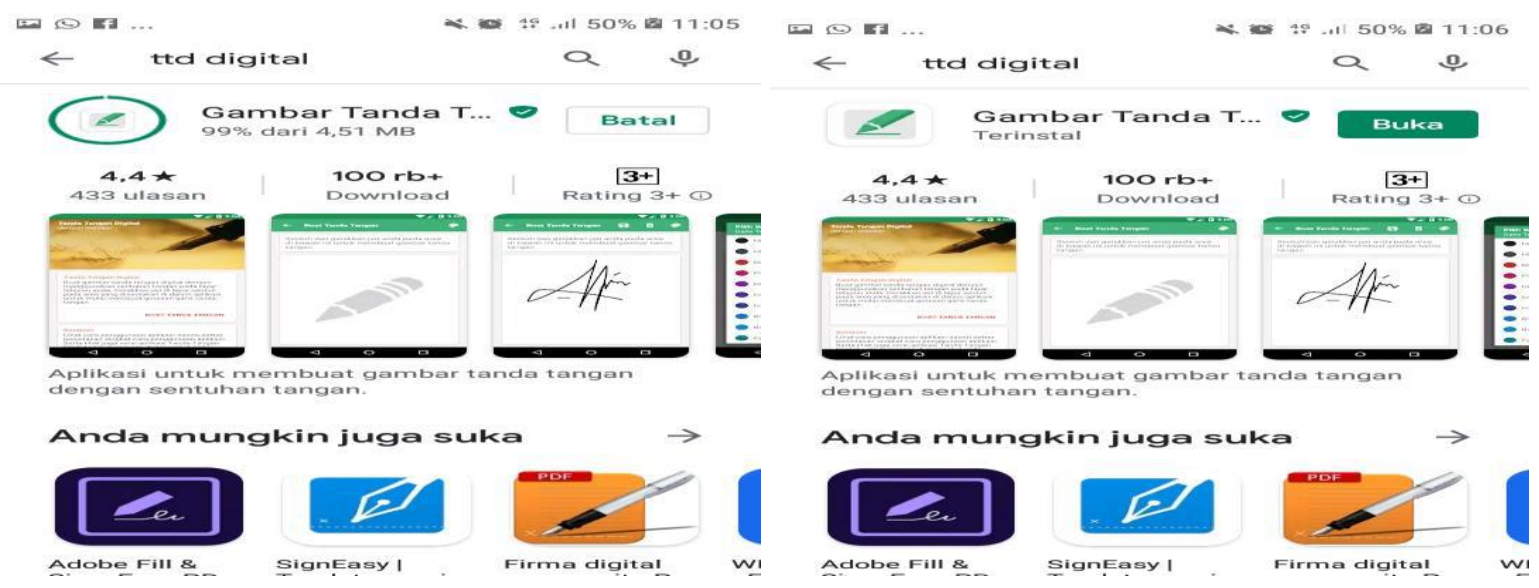

Gambar 3. Instalasi TTDigital

\section{Pengoprasian TTDigital}

Langkah awal pengoprasian aplikasi TTDigital dilakukan dengan membuka aplikasi yang diikuti dengan memilih button buat tandatangan. Handphone pengguna akan secara otomatis memunculkan notifikasi izin aplikasi seperti disajikan pada Gambar 4.
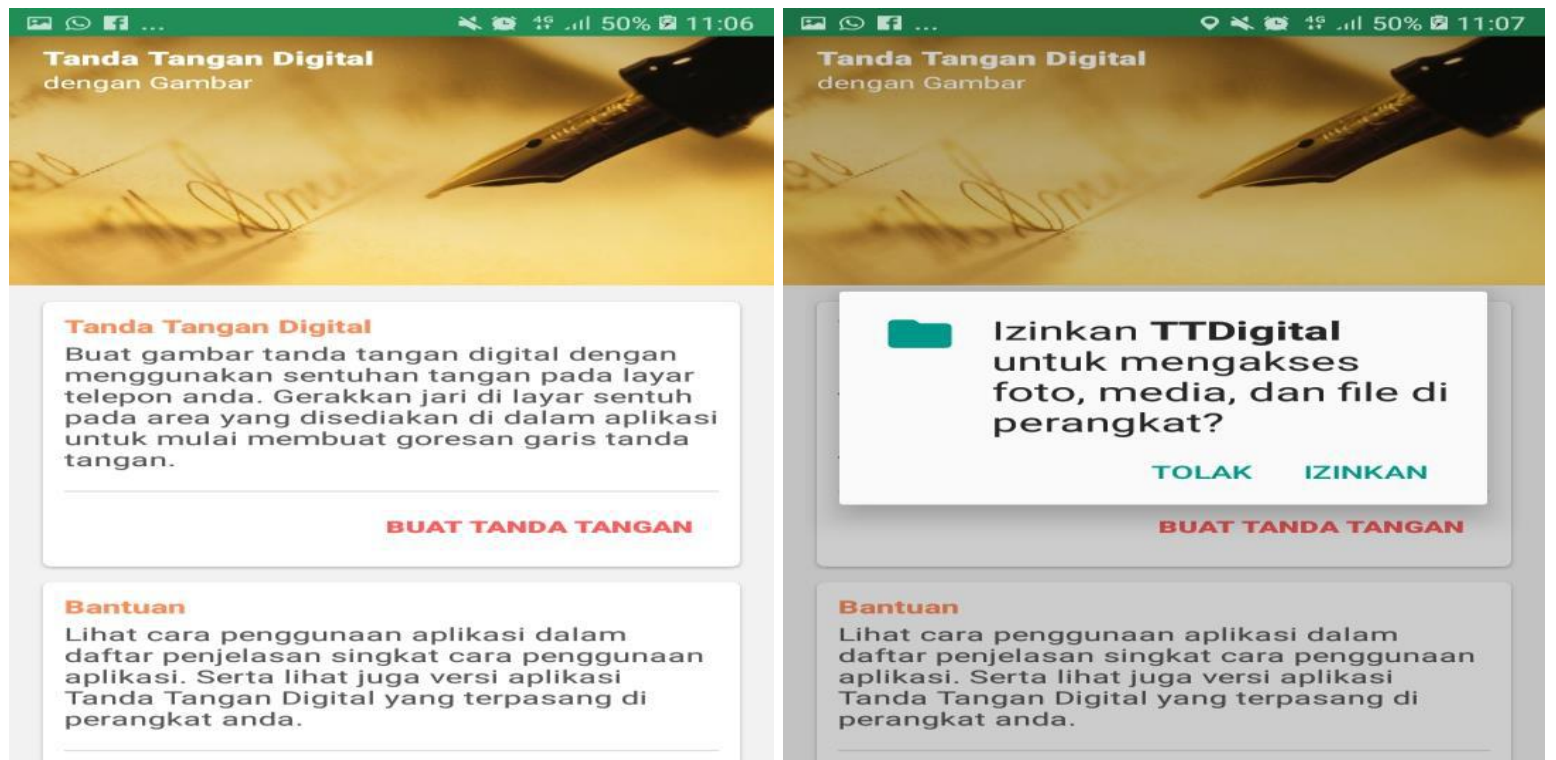

Gambar 4. Pengoperasian awal TTDigital

Langkah selanjutnya adalah pembuatan tandatangan. Hasil pembeuatan tandatangan yang terekam dalam aplikasi selanjutnya akan disimpan pada directory penyimpanan local perangkat pengguna. Langkah pembuatan tandatangan secara singkat disajikan pada Gambar 5.

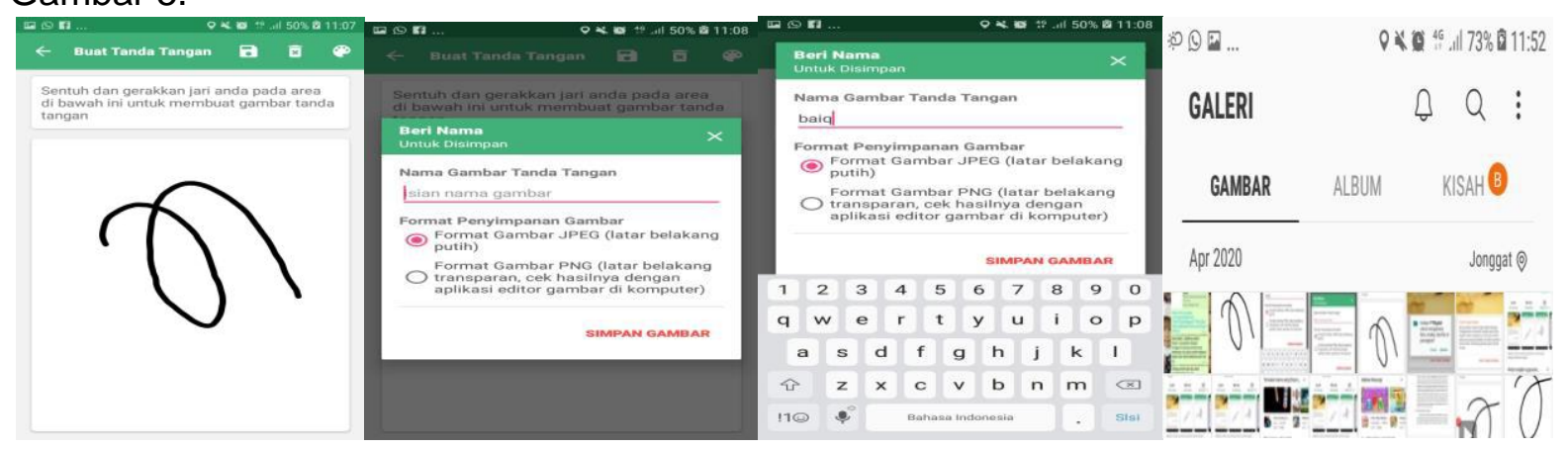

Gambar 5. Pembuatan tandatangan digital. 


\section{Mengisi absen online}

Peserta pelatihan melakukan pengisian presensi secara online melalui link yang sudah dikirimkan dan memilih tanda (+) untuk mengikuti kegiatan pelatihan seperti disajikan pada Gambar 6.

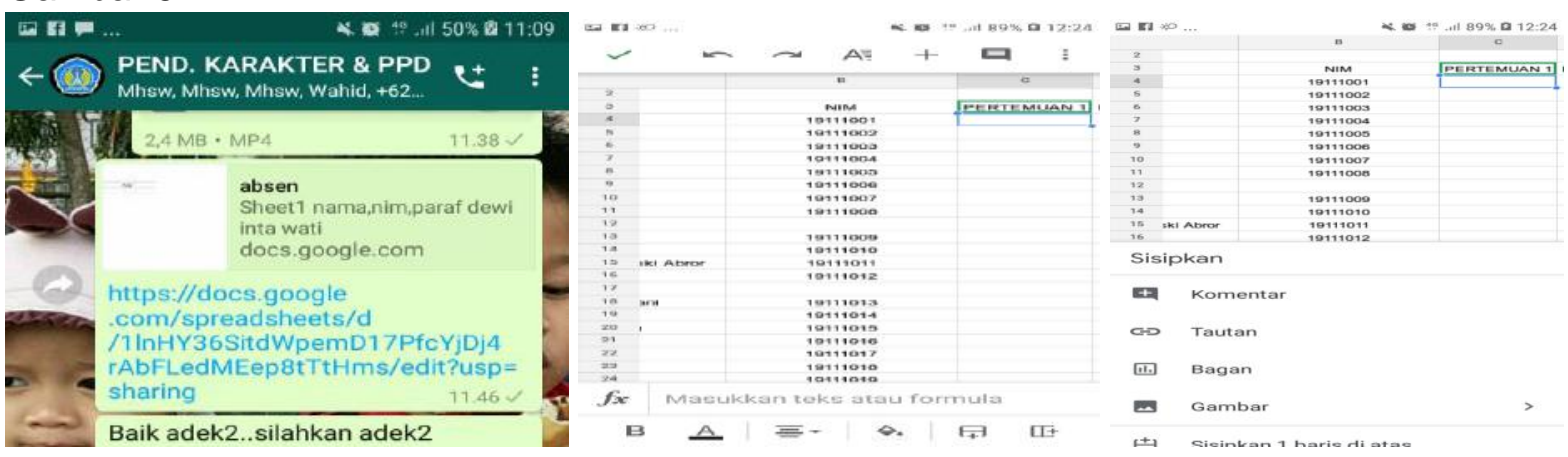

Gambar 6. Pengisian presensi oleh peserta

Pada tahapan ini, peserta dapat mengupload tandatangan digital yang dimiliki melalui aplikasi TTDigital dengan mengklik gambar tandatangan yang dimiliki sehingga aplikasi akan mengarah pada lembar presensi perkuliahan seperti disajikan pada Gambar 7.

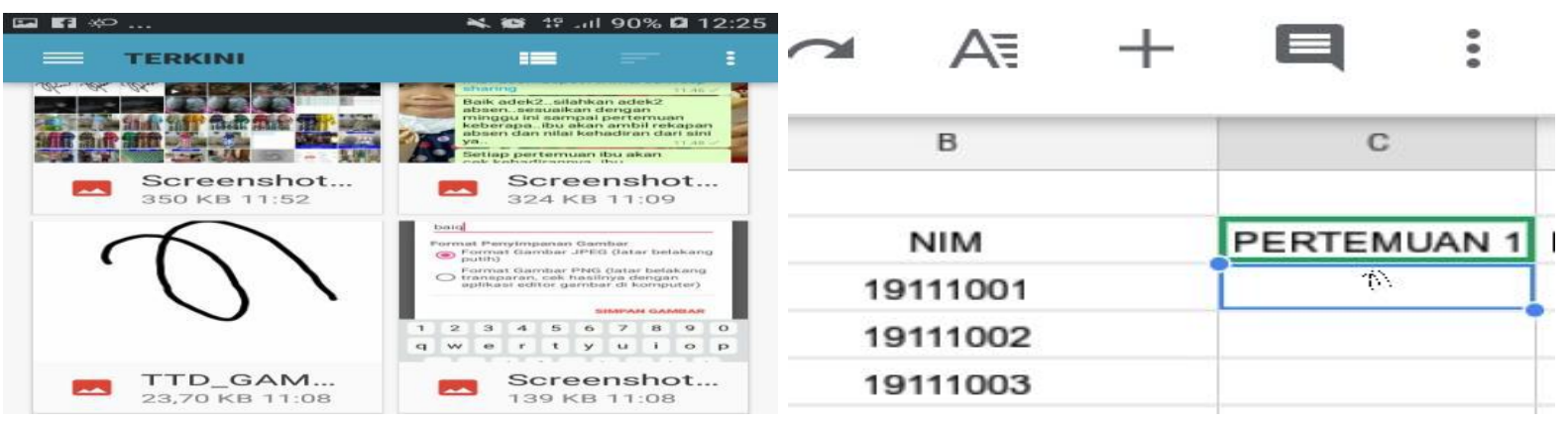

Gambar 7. Tampilan pengisian tanda-tangan digital peserta

Selama pelatihan berlangsung dengan menggunakan whatsaap berupa video call group terlihat para peserta sangat semangat dan antusias, dilihat dari para peserta langsung mempraktekkannya. Bila ada yang kurang jelas dari awal materi, para peserta sangat aktif dan tidak sungkan-sungkan untuk bertanya dan saling membantu. Pelatihan ini juga memperlihatkan bahwa mahasiswa yang hadir $100 \%$ dalam perkuliahan yakni terbukti dengan 16 kali tanda tangan digital yang di isi secara on line dan apabila terdapat mahasiswa dengan kosong tanda tangan digital berarti mahasiswa tersebut tidak mengikuti perkuliahan. Hal ini dapat dilihat pada Gambar 8 berikut.

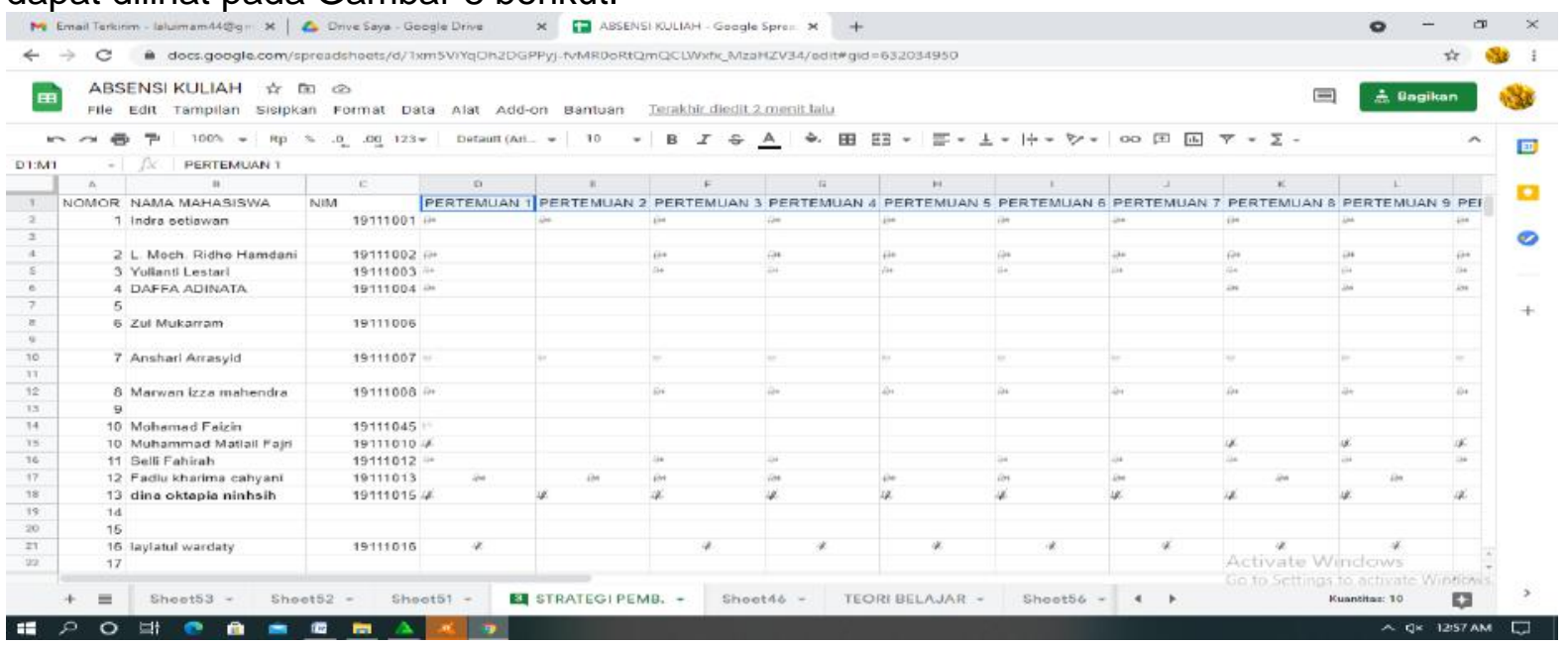

Gambar 8. Hasil presensi peserta pelatihan 


\section{KESIMPULAN}

Pelatihan ini mampu membuat mahasiswa membuat tanda tangan digital untuk mengisi kehadiran (presensi) perkuliahan secara online.

\section{REKOMENDASI}

Aplikasi TTDigital dapat menjadi solusi alternative pelaksaan pengisian presensi mahasiswa dalam perkuliahan, terutama pada masa pandemic Covid-19.

\section{DAFTAR PUSTAKA}

Ainun. (2019). Pengertian Google Drive: Fungsi, Manfaat dan Cara Menggunakan. (Diakses tanggal 24 Agustus 2020, https://www.salamadian.com/pengertian-google-drive/).

Ermi, N. (2015). Penggunaan Metode Diskusi untuk Meningkatkan Hasil Belajar Materi Perubahan Sosial pada Siswa Kelas XII SMA Negeri 4 Pekanbaru. Jurnal SOROT, 10 (2), $155-168$.

Ferry, L. (2014). Metode Latihan (Drill) untuk Meningkatkan Hasil Belajar Peserta Didik dalam Menggambar Autocad. Journal of Mechanical Engineering Education, 1 (2), 246-254.

Hestanto. (2020). Pengertian Tanda Tangan Digital. (Diakses tanggal 24 Agustus 2020, https://www.hestanto.web.id/tanda-tangan-

digital/amp/\#aoh=15982717990850\&referrer=https\%3A\%2Fwww.google.com\&amp tf =Dari\%20\%251\%24s\&ampshare=https\%3A\%2F\%2Fwww.hestanto.web.id\%2Ftandatangan-digital\%2F).

Indah. (2020). 4 Alasan Pentingnya Absensi Online di Era Revolusi Industri 4.0. (Diakses tanggal 24 Agustus 2020, https://infokomputer.grid.id/read/121950682/4-alasanpentingnya-absensi-online-di-era-revolusi-industri-40?page=all).

Kompas. (2014). Presensi Min. 75\%: Merasakan Aturan Semanis Susu. (Diakses tanggal 24 Agustus

2020 , https://www.kompasiana.com/siawliem/54f5defea333111f1f8b47a6/presensi-min-75merasakan-aturan-semanis-susu).

Kompas. (2013). Absensi' Maknanya 'Kehadiran' atau 'Ketidakhadiran' Sih?. (Diakses tanggal $\begin{array}{lll}24 & \text { Agustus } & 2020,\end{array}$ https://www.kompasiana.com/gustaafkusno/552ff6ce6ea8344d768b4588/absensimaknanya-kehadiran-atau-ketidakhadiran-sih).

Program Studi Pendidikan Teknologi Informasi. 2015. Buku pedoman akademik Prodi Pendidikan Teknologi Informasi. FPMIPA IKIP Mataram.

Rusman. (2011). Model-Model Pembelajaran Mengembangkan Profesionalisme Guru. Jakarta: PT. Raja Grafindo Persada.

Samani, M. 2012. Konsep dan Model Pendidikan Karakter. Bandung: PT Remaja Rosdakarya. 